\title{
Evaluation of CRP in Patients with Asthma
}

\author{
Karthika M1, Prakash Chandra Bhardwaj', Deisha B Rymbuiं ${ }^{3}$, W Kanan ${ }^{4}$, W Asoka Singh ${ }^{5}$ \\ ${ }^{I}$ Senior Resident, Department of Physiology, JIPMER, Puducherry, ${ }^{2} M D$ (Physiology), Department of Health \\ Services, Manipur, ${ }^{3} M D$ (Physiology), Department of Health Services, Meghalaya, ${ }^{4}$ Professor \& Head Department \\ of Physiology, Regional Institute of Medical Sciences, Imphal, Manipur, ${ }^{5}$ Professor Department of Respiratory \\ Medicine, Regional Institute of Medical Sciences, Imphal, Manipur
}

\begin{abstract}
Patients with asthma have an ongoing inflammation, which can be assessed by measuring serum C- reactive protein.

Objective: To explore whether CRP could be used as a predictor of disease outcome in asthma. Methods: A Cross-sectional study was conducted among 50 asthma patients attending Respiratory Medicine outpatient services in Regional Institute of Medical Sciences (RIMS), Imphal from January 2015 to September 2016. Patients aged 18-67 were included in the study after obtaining Ethical approval from the Research Ethics Board, RIMS, Imphal. Computerized Spirometer Helios 401 was the instrument used to measure lung volumes and capacities. BeneSphera ${ }^{\mathrm{TM}}$ CRP Latex Slide test kit was used to estimate serum C-reactive protein.
\end{abstract}

Results and Observation: The present study was conducted on fifty asthma patients in which serum CRP level showed association with severity of asthma $(\mathrm{p}=0.001)$ but serum CRP level with spirometric parameters showed significant negative correlation; FVC $(r=-0.711, \mathrm{p}<0.001), \mathrm{FEV}_{1}(\mathrm{r}=-0.665, \mathrm{p}<0.001)$, $\mathrm{FEV}_{1} / \mathrm{FVC}(\mathrm{r}=-0.429, \mathrm{p}=0.002), \mathrm{FEF}_{25-75 \%}(\mathrm{r}=-0.535, \mathrm{p}<0.001)$, and $\operatorname{PEFR}(\mathrm{r}=-0.515, \mathrm{p}<0.001)$.

Conclusion: In our study we found association between serum CRP level and asthma and plasma CRP may be used as a marker of prognosis in patients with asthma.

Keywords : C-reactive protein, Asthma

\section{Introduction}

Asthma is one of the most common chronic disease and currently affects nearly 300 million people globally. The prevalence of asthma has risen in affluent countries over the past 30 years with $10-12 \%$ of adults and $15 \%$ of children affected by the disease. ${ }^{1}$

The NHLBI (National Heart Lung and Blood Institute, US) defined asthma in 2002 as: a chronic inflammatory disorder of the airways in which many cells and cellular elements play a role. ${ }^{2}$ The chronic inflammation of the airway causes recurrent episodes of

\section{Corresponding author:}

Dr. Karthika

M, Senior Resident, Department of Physiology, JIPMER, Puducherry. wheezing, chest tightness, breathlessness, and coughing, particularly at night and in the early morning. These episodes are usually associated with wide spread but variable airflow obstruction that is often reversible either spontaneously or with treatment. ${ }^{2}$

Diagnosis is based on the patient's history, signs, and symptoms, and on the results of spirometry and other pulmonary function tests. Spirometry assesses the obstruction of expiratory airflow, which is the characteristic functional defect. Spirometry is the most effective way of determining the severity of obstructive airway diseases. ${ }^{3}$

C-reactive protein was first isolated in 1930 and was named so because it binds to the C-polysaccharide of the pneumococcus. CRP was first found in the plasma of patients with pneumococcal pneumonia. Modern 
molecular studies have determined that CRP is a member of the pentraxin family of proteins. It comprises five protomers, each of 206 amino acids, molecular weight $23 \mathrm{kDa}$, arranged in cyclic symmetry. With the participation of $\mathrm{Ca}^{+2}$ ions, it binds various proteins and phospholipids, particularly phosphocholine. It opsonizes particles and also activates complement via the classical pathway, but its actual biological function is unknown. ${ }^{4}$

C-reactive protein is an abnormal protein that appears in blood in the acute stages of various inflammatory disorders but is undetectable in the blood of healthy persons. ${ }^{5}$

C-reactive protein is an acute phase protein synthesized in the liver during infection, injury and systemic inflammatory conditions. Worldwide studies had shown that it has variable roles in asthma, some showing correlation with spirometric lung function while others with no significant relation. Hence this study was planned to explore its role in the population and also to determine whether it could become an independent predictor of disease outcome in asthma.

\section{Method}

Study design A Cross-sectional study was conducted among 50 asthma patients attending Respiratory Medicine outpatient services in Regional Institute of Medical Sciences (RIMS), Imphal from January 2015 to September 2016. Patients aged 18-67 were included in the study after obtaining Ethical approval from the Research Ethics Board, RIMS, Imphal. The participants were recruited by Purposive sampling. Diagnosed asthma patients sent from Respiratory Medicine OPD, RIMS, Imphal were included in this study. Socio-demographic characteristics like age, sex, smoking history were recorded. Thorough physical examination, degree of airflow obstruction and serum $\mathrm{C}$-reactive protein were recorded after obtaining Prior written informed consent form from all the participants.

The patients with chronic disorders like hypertension, diabetes mellitus, cardiovascular diseases, bleeding disorders, inflammatory disorders, infection , malignancy and patients who had recent surgery were excluded from the study.

Computerized Spirometer Helios 401 of the Recorders and Medicare System, Chandigarh,India was the instrument used to measure lung volumes and capacities. The Helios software contains set of prediction equations for computation of predicted parameter values.

The procedure was explained to the patient followed by a demonstration. The patient was asked to "take as deep a breath as possible" and then "blast as fast and hard as you can" and "keep blowing until I ask you to stop" preferably at least 3 seconds followed by a rapid inhalation (inspiration). A tight seal was ensured around the mouthpiece. During the test, soft nose clip was used to prevent air escaping through the nose. Coaching was active and vigorous; instructions were repeated as necessary. Three consecutive maneuvers were performed with a rest of 5 to 10 minutes between two maneuvers.

The best result among the three tests were recorded in the proforma. The results were compared with the predicted values for the same age, sex, height, and weight.

The study variables which include Forced Vital Capacity (FVC), Forced Expiratory Volume in one second $\left(\mathrm{FEV}_{1}\right), \mathrm{FEV}_{1} / \mathrm{FVC}$ ratio, Forced Expiratory Flow during $25-75 \%$ of expiratory flow (FEF ${ }_{25-75 \%}$ ), and Peak Expiratory Flow Rate (PEFR), were recorded by Helios Computerized Spirometer Model No. 401, in a sitting position. Patients were classified on the basis of GINA Classification of asthma(2006) ${ }^{6}$

BeneSphera $^{\mathrm{TM}}$ CRP Latex Slide test kit of Avantor Performance Materials India Ltd, Dehradun, Uttarakhand, was used to estimate serum c-reactive protein in human. The test was expected to be positive with serum CRP levels between 0.6 and $100 \mathrm{mg} / \mathrm{dl}$.

\section{Statistical Analysis}

The collected data were entered and analyzed using IBM SPSS Statistics V21.0 (IBM Corporation, US). Summarizations of data for frequency distribution for variables of interest were carried out by using descriptive statistics such as mean, standard deviation and percentages. Chi-square test was employed to test the association between asthma with variables of interest. A p-value of $<0.05$ was considered significant.

\section{Results and Observation}

A total of 50 patients with asthma were included in the study. Of which $36 \%$ of patients belonged to the age group (38-67years) and 64\% of the patients belong to age group (18-37years). About two third of the Obstructive Airway Disease patients were male. Out of 50, $82 \%$ patients were non-smoker, $12 \%$ were smoker, and $6 \%$ 
were ex smokers. Socio-demographic characteristics like age, sex, smoking history were recorded. Thorough physical examination, degree of airflow obstruction and serum C-reactive protein were recorded after obtaining Prior written informed consent from from all the participants.

Patients were classified on the basis of GINA Classification of asthma. In our study group shows
$46 \%$ belonged to intermittent persistent category of asthma $\left(\mathrm{FEV}_{1} \geq 0.80\right.$ and PEF variability $\left.<20 \%\right)$, and $20 \%$ were in mild persistent category $\left(\mathrm{FEV}_{1} \geq 0.80\right.$ and PEF variability $20-30 \%$ ). $16 \%$ of the patients were in moderate persistent category $\left(\mathrm{FEV}_{1}=0.60-0.80\right.$ and $\mathrm{PEF}$ variability $>30 \%$ ), while $18 \%$ of the patients were in very severe persistent category $\left(\mathrm{FEV}_{1} \leq 0.60\right.$ and $\mathrm{PEF}$ variability $>30 \%$ ).

Table 1: Mean \pm SD of FVC, FEV, FEV $_{1} /$ FVC, FEF25-75\%, and PEFR in Asthma patients $(\mathrm{N}=50)$

\begin{tabular}{|l|l|l|l|l|}
\hline $\begin{array}{l}\text { Spirometric } \\
\text { parameters }\end{array}$ & $\begin{array}{l}\text { Minimum } \\
\text { Value(\%pred) }\end{array}$ & $\begin{array}{l}\text { Maximum } \\
\text { Value(\%pred) }\end{array}$ & Mean(\%pred) & Standard Deviation \\
\hline FVC & 47.00 & 149.00 & 100.02 & 24.64 \\
\hline FEV1 & 28.00 & 138.00 & 90.82 & 30.42 \\
\hline FEV1/FVC & 42.00 & 115.00 & 89.26 & 15.10 \\
\hline FEF25-75\% & 7.00 & 138.00 & 58.18 & 30.91 \\
\hline PEFR & 15.00 & 107.00 & 63.40 & 23.52 \\
\hline
\end{tabular}

Table 1 shows the lung function test values of Asthma patients as measured by spirometer. All the values were within normal limit.

Table 2: Association of the serum CRP level with the severity of Asthma

\begin{tabular}{|c|c|c|c|c|c|}
\hline \multirow[b]{2}{*}{$\begin{array}{l}\text { Severity of } \\
\text { Asthma }\end{array}$} & \multicolumn{3}{|l|}{ CRP } & \multirow[b]{2}{*}{ Total } & \multirow[b]{2}{*}{ p-value* } \\
\hline & LESS THAN 6mg/L & $6 \mathrm{mg} / \mathrm{L}$ & $12 \mathrm{mg} / \mathrm{L}$ & & \\
\hline $\begin{array}{l}\text { Intermittent } \\
\text { Mild } \\
\text { Moderate } \\
\text { Severe } \\
\text { Total }\end{array}$ & $\begin{array}{l}22 \\
10 \\
5 \\
2 \\
39\end{array}$ & $\begin{array}{l}1 \\
0 \\
3 \\
3 \\
7\end{array}$ & $\begin{array}{l}0 \\
0 \\
0 \\
4 \\
4\end{array}$ & $\begin{array}{l}23 \\
10 \\
8 \\
9 \\
50\end{array}$ & $<0.001$ \\
\hline \multicolumn{6}{|c|}{$\begin{array}{l}\text { *Chi-Square Test } \\
\text { Table } 2 \text { shows that the association between the serum CRP level with the severity of asthma. Patients with intermittent ( } 44 \% \text { of } \\
\text { asthmatic patients) and mild ( } 20 \% \text { of asthmatic patients) persistent asthma had serum CRP level }<6 \mathrm{mg} / \mathrm{L} \text {. Total } 7(14 \%) \text { patients } \\
\text { had serum CRP level } 6 \mathrm{mg} / \mathrm{L} \text {, in which } 1(2 \%) \text { patient belong to intermittent asthma, } 3(6 \%) \text { patients were in each moderate and } \\
\text { severe persistent category of asthma. Out of } 9 \text { severe asthmatic patients } 4 \text { had serum CRP level } 12 \mathrm{mg} / \mathrm{L} \text { ( }<<0.001) \text {. }\end{array}$} \\
\hline
\end{tabular}


Table 3: Association of the serum CRP level with the Visiting day to hospital OPD of Asthmatic patients after asthma attack

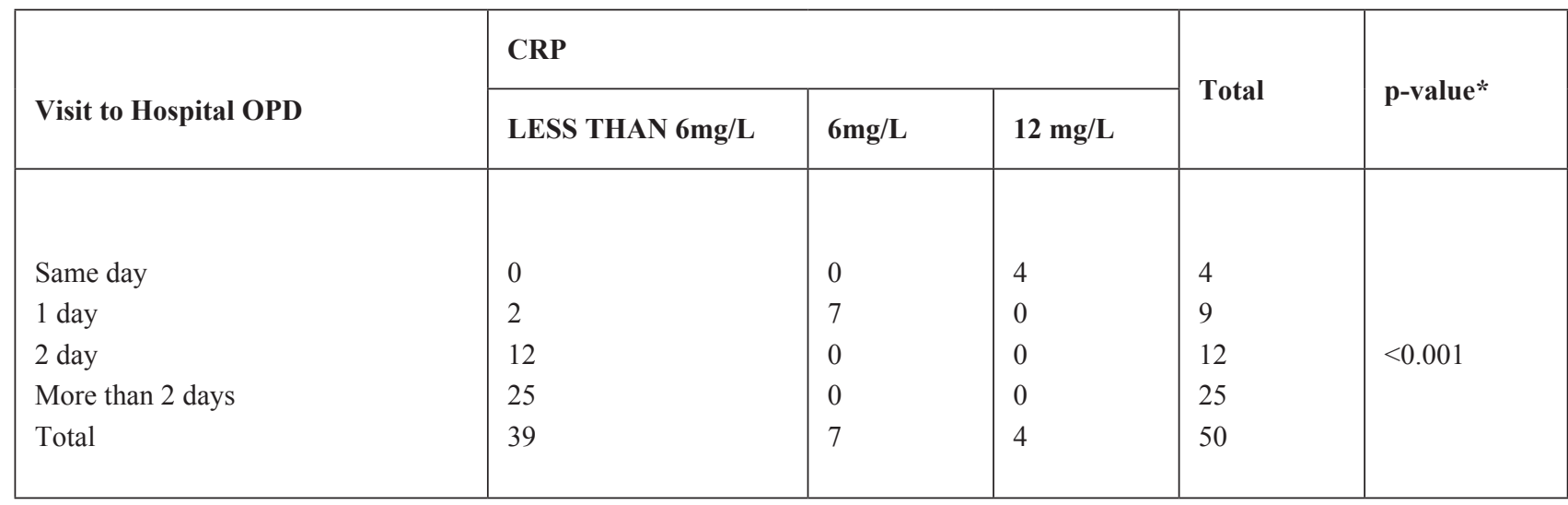

\section{*Chi-Square Test}

Above table shows that association between level of serum CRP in asthma patients with the visiting day to hospital OPD after exaggeration of symptoms. Those asthma patients ( $8 \%$ of asthma patients) who were visited same day of exaggeration of symptoms had serum CRP level $12 \mathrm{mg} / \mathrm{L}$, while those asthma patients $(74 \%$ of asthma patients) who were visited after 2 or more days had serum CRP level $<6 \mathrm{mg} / \mathrm{L}(\mathrm{p}<0.001)$.

Table 4: Correlation of different parameters of spirometry with serum CRP level in Asthma patients $(\mathbf{n}=\mathbf{5 0})$

\begin{tabular}{|l|l|l|}
\hline Parameter & Correlation coefficient(r)* & p-value \\
\hline FVC & -0.711 & $<0.001$ \\
\hline FEV1 & -0.665 & $<0.001$ \\
\hline FEV1/FVC & -0.429 & 0.002 \\
\hline FEF25-75\% & -0.535 & $<0.001$ \\
\hline PEFR & -0.515 & $<0.001$ \\
\hline
\end{tabular}

*Pearson`s bivariate correlation coefficient

Above table shows that in asthma patients serum C-reactive protein level were significantly correlated with spirometric lung parameters.

\section{Discussion}

Obstructive airway disease (OAD) is a disorder characterized by chronic inflammation of airways which leads to lung function impairment. The term OAD includes bronchial asthma and chronic obstructive pulmonary disease. Inflammation plays an important role in the pathogenesis of asthma. C-reactive protein is an acute phase protein produced by liver during inflammation or injury in the body. Higher level of CRP in blood during exacerbation of obstructive airway disease is not uncommon. However, the ability of serum CRP in predicting asthma control has not been sufficiently investigated yet. We would therefore like to explore its role in our study population and also try to explore whether it could become an independent predictor of disease outcome in asthma.

The present study was conducted on fifty asthma patients in which serum CRP level showed association with severity of asthma ( $p=0.001)$ but serum CRP level with spirometric parameters showed significant negative correlation; FVC $(r=-0.711, \mathrm{p}<0.001), \mathrm{FEV}_{1}(\mathrm{r}=-0.665$, $\mathrm{p}<0.001), \mathrm{FEV}_{1} / \mathrm{FVC}(\mathrm{r}=-0.429, \mathrm{p}=0.002), \mathrm{FEF}_{25-75 \%}(\mathrm{r}=-$ $0.535, \mathrm{p}<0.00<)$, and PEFR $(\mathrm{r}=-0.515, \mathrm{p}<0.001)$. 
Increased serum high sensitive C-reactive protein (hs-CRP) in asthma and its association with the disease has been investigated in many studies. In this study significant association was found between serum CRP level and severity of asthma $(\mathrm{p}<0.001)$. These results were supported by other authors, such as Zietkowski Z et $\mathrm{al}^{28}$ reported that serum levels of hs-CRP in all groups of asthmatics were significantly higher than those measured in healthy volunteers. Kilic $\mathrm{H}$ et $\mathrm{al}^{39}$ also noted a significant positive correlation between the levels of hs-CRP and the severity of asthma $(p=0.04, r=0.38)$.

Furthermore, a recent population-based study by Kony $\mathrm{S}$ et al showed associations of increased levels of serum hs-CRP with a high frequency of airway hyperresponsiveness and low forced expiratory volume in one second $\left(\mathrm{FEV}_{1}\right)$ among subjects without heart disease $^{7}$, suggesting that systemic inflammation may be associated with respiratory impairment. Another recent epidemiological study by Olafsdottir IS et al showed that elevated levels of hs-CRP correlate significantly with respiratory symptoms and with prevalence of nonallergic asthma ${ }^{8}$.

Sävykoski $T$ et al found that the difference in hsCRP levels remained significant when the comparison was confined to patients with moderate asthma and healthy controls with a normal BMI $\left(<25 \mathrm{~kg} \cdot \mathrm{m}^{-2}\right)$ or nonsmokers 9 . In another study by Shimoda et al., the log serum hs-CRP of 2.3 distinguished asthmatic patients from healthy controls at sensitivity of $69 \%$ and specificity of $70 \%{ }^{10}$

In the study by M. Takemura et al, patients with steroid-naive asthma showed increased serum hs-CRP levels compared with healthy controls. Moreover, serum hs-CRP levels correlated negatively with $\mathrm{FEV}_{1}$, $\mathrm{FEV}_{1} / \mathrm{FVC}$ and $\mathrm{FEF}_{25-75 \%}$, positively with numbers of sputum eosinophils and marginally with numbers of macrophages and neutrophils ${ }^{11}$ which was similar to our study.

\section{Conclusion}

In this study significant association was found between serum CRP level and severity of asthma $(\mathrm{p}<0.001)$. This study has limitations regarding study design which is cross-sectional. The serum CRP has been used for evaluation of treatment in chronic pulmonary airway disease and other inflammatory conditions but several factors other than the presence of asthma might affect serum levels of CRP. CRP may be elevated in obese individuals and also in people who have the habit of smoking. Ageing is also another confounding factor. Another limitation of this study is lack of steroid naive asthma patients. Treatment of patients with corticosteroids may reduce the level of serum CRP. Further longitudinal studies are necessary to evaluate whether CRP could be used an independent predictor of disease outcome in asthma.

Ethical Clearance- Ethical approval was obtained from the Research Ethics Board, RIMS, Imphal before the beginning of the study.

\section{Source of Funding- Self \\ Conflict of Interest - Nil}

\section{References}

1. Asher MI, Montefort S, Björkstén B, Lai CK, Strachan DP, Weiland SK, et al. Worldwide time trends in the prevalence of symptoms of asthma, allergy rhinoconjunctivitis, and eczema in childhood: ISAAC phases one and three repeat multicountry cross-sectional surveys. Lancet 2006;368(9537):733-43.

2. Global strategy for the diagnosis, management, and prevention of chronic obstructive pulmonary disease (2006). Available at: http://www.goldcopd. org. Accessed September 19, 2016.

3. Bellamy D. Spirometry in practice: a practical guide to using spirometry in primary care. 2 nd ed. London: BTS COPD Consortium; 2005.

4. Block JL. Evaluation of cardiac injury and function. In: McPherson RA, Pincus MR, editors. Henry`s Clinical Diagnosis and Management by Laboratory Methods. 21st ed. New Delhi: Elsevier; 2009. p. 224-5.

5. Sonnenwirth AC. Serological tests in infectious disease-II. In: Sonnenwirth, Jarett L, editors. Gradwohl's Clinical Laboratory Methods and Diagonosis. 8th ed. New Delhi: B.I. Publications Ltd; 1990. p. 2328-31.

6. Koshak EA. Classification of asthma according to revised 2006 GINA: Evolution from severity to control. Ann Thorac Med 2007;2(2):45-6.

7. Kony S, Zureik M, Driss F, Neukirch C, Leynaert B, Neukirch F. Association of bronchial hyperresponsiveness and lung function with C-reactive protein (CRP): a population based study. Thorax 2004;59:892-896. 
8. Olafsdottir IS, Gislason T, Thjodleifsson B, et al. $C$ reactive protein levels are increased in nonallergic but not allergic asthma: a multicentre epidemiological study. Thorax 2005;60:451-454.

9. Sävykoski T, Harju T, Paldanius M, et al. Chlamydia pneumoniae infection and inflammation in adults with asthma. Respiration 2004;71:120-125.
10. 15. Shimoda T, Obase Y, Kishikawa R, Iwanaga T. Serum high-sensitivity C-reactive protein can be an airway inflammation predictor in bronchial asthma. Allergy Asthma Proc. 2015;36:e23-8.

11. M. Takemura, H. Matsumoto, A. Niimi, T. Ueda, H. Matsuoka, M. Yamaguchi, et al. High sensitivity C-reactive protein in asthma. Eur Respire J 2006; 27: 908-912. 